Article

\title{
Using Network Theory to Explore BIM Application Barriers for BIM Sustainable Development in China
}

\author{
Yongliang Deng ${ }^{1,2}$, Jinyun $\mathrm{Li}^{1, *}$, Qiuting $\mathrm{Wu}^{1}$, Shuangshuang Pei ${ }^{1}, \mathrm{Na} \mathrm{Xu}^{1,2}{ }^{1 \mathbb{D}}$ and \\ Guodong Ni ${ }^{1,2}$ \\ 1 School of Mechanics and Civil Engineering, China University of Mining and Technology, \\ Xuzhou 221116, China; dylcumt@cumt.edu.cn (Y.D.); qstingw@cumt.edu.cn (Q.W.); \\ Peiss0827@cumt.edu.cn (S.P.); xuna@cumt.edu.cn (N.X.); niguodong@cumt.edu.cn (G.N.) \\ 2 Research Center for Digitalized Construction and Knowledge Engineering, China University of Mining \\ and Technology, Xuzhou 221116, China \\ * Correspondence: ts18030143p31@cumt.edu.cn
}

Received: 23 February 2020; Accepted: 9 April 2020; Published: 15 April 2020

check for

\begin{abstract}
Building Information Modeling (BIM) technology has promoted the development of the architecture, engineering, and construction (AEC) industry, but has encountered many barriers to its application in China. Therefore, identifying the barriers to BIM application and capturing their interactions are essential in order to control and eliminate the determined barriers. From this standpoint, 23 BIM application barriers were identified through a literature review and expert interviews. Furthermore, the interactions among them were determined based on the Delphi method, which was the foundation for establishing the BIM application barrier network (BABN). Then, the software Pajek was employed to construct the network model and reveal its topological characteristics based on complex network theory, including degree, betweenness, eigenvector, clustering coefficient, network diameter, and average path length. As indicated by the results, BABN possesses scale-free network property because its cumulative degree distribution obeys power-law distribution. BABN is also a small-world network, due to its relatively high clustering coefficient as well as small average path length, implying that barrier propagation in BABN is fast. In addition, the results are discussed and recommendations are proposed. This research will help BIM stakeholders to develop coping strategies to control and eliminate BIM application barriers for the sake of driving BIM sustainable development.
\end{abstract}

Keywords: building information modeling; application barrier; complex network theory; Pajek

\section{Introduction}

The architecture, engineering, and construction (AEC) industry has long been criticized for its low productivity, especially in the complicated engineering construction projects [1]. The AEC industry becomes complex and difficult to manage. In recent years, the low efficiency of production in the AEC industry has drawn wide attention. For the purpose of sustainable development, the AEC industry urgently needs a new technique to change its current situation.

Research conducted by Stanford University's Center for Integrated Facilities Engineering (CIFE) on 32 large-scale construction projects has shown that the application of building information modeling (BIM), compared with previous working modes, reduces $80 \%$ of the time spent in project budget estimation, eliminates $40 \%$ of unbudgeted changes, saves $10 \%$ in contract value, decreases $7 \%$ of the total project duration, and creates a 3\% profit margin for the entire project [2]. According to the study performed by Franz and Messner, when BIM use adoption increased by one unit, the average project delivery speed increased by 19.4\% [3]. Another study conducted by Min et al. [4] 
showed that applying BIM can reduce errors in the project, which reduces the cost compared to the up-front cost brought by applying BIM. As a digital technology, BIM can reduce cost throughout the building's lifecycle [5]. It can be utilized to support design, procurement, fabrication, construction, operation, and maintenance, such as cost management, time management, risk management, resource management, facility management, and sustainable applications. In short, BIM offers the potential to help transform the construction industry and boost productivity in the AEC industry [6].

As the application of BIM helps to promote the sustainable development of the AEC industry, many governments are actively promulgating policies to accelerate the process of BIM adoption, including the United States, China, the United Kingdom, Singapore, and others [7]. The government has been an active advocate of BIM application. The Chinese AEC industry is one of the biggest and most important markets in the world, and it also plays a pivotal role in China's economy. Recently, the Chinese government has been actively promoting the development of BIM technology in China. The study conducted by Lin and Zhang [8] indicated that China's national government, local government, and association issued a total of 58 BIM-related policies from December 2013 to December 2017, and the number of polices demonstrated a typical exponential growth trend. It can be inferred that the relevant state agencies will increasingly be issued along with the development of BIM.

Compared with the continuous release of government policies, China's AEC industry shows less enthusiasm about adopting BIM. A study conducted by Dodge Data \& Analytics have found that nearly half $(46 \%)$ of the architects and a third (31\%) of the contractors in China are currently at the lowest level of BIM application [9]. The latest survey conducted by the China Construction Industry Association shows that nearly a third of companies (34.79\%) apply BIM in less than a quarter of their company's projects, only $24.54 \%$ of enterprises apply BIM for more than $50 \%$ of their enterprise projects [10]. Many projects that adopt BIM are forced to use BIM due to government pressure, and these projects are often "half" or "fake" BIM projects [11]. These data indicate that BIM application in China's AEC industry is difficult to advance due to various barriers. These barriers obstruct BIM sustainable development in multiple ways. Therefore, it is critical to identify and control the key barriers in order to promote the development of BIM in China.

The purpose of this study is to identify barriers encountered in current BIM application, analyze the relationships between these barriers, and identify key barriers. This paper can help BIM stakeholders to formulate more practical and effective BIM application strategies, thereby promoting the sustainable development of BIM in China. To do this, a new analytical framework is firstly proposed. Then, the barriers are summarized from grounded theory and a literature review to get the final 23 BIM application barriers. Next, the relationships between barriers are determined through the Delphi method. Subsequently, the network model is established and analyzed scientifically. Based on the research findings and discussions, recommendations for promoting the application of BIM technology are proposed and discussed. This research has the potential to develop a better understanding of the barriers to BIM application, and offers some beneficial references and thoughts for the healthy and persistent development of BIM in AEC industry in a long run.

After this introduction, the rest of paper is organized as follows. In Section 2, a detailed literature review summarizes the themes of the definition of BIM, BIM application, and stakeholder analysis, and the research status of BIM application barriers. Section 3 describes the methodology used in this study, including the analytical framework, data collection and analysis, ground theory, and network modeling and analysis. The results are presented in Section 4. A discussion of, and recommendations concerning, possible application issues are provided in Section 5. Conclusions and opportunities for future research are offered in Section 6.

\section{Previous Technical Related Literature: A Review}

BIM technology has experienced nearly half a century of development in the field of AEC industry, from its infancy to its mature application. A prototype of BIM was first proposed in 1975 by Professor Chuck Eastman of the Georgia Institute of Technology. He proposed to "build a computer-based 
description of a building" to realize the visualization and quantitative analysis and improve the efficiency of construction projects [12]. In the following decades, BIM has gradually become the focus of attention in the AEC industry [13]. The definition of BIM has also evolved along with its development and application. Eastman first described BIM as "a modeling technology and associated set of processes to produce, communicate, and analyze building models". After that, scholars have enriched the definition of BIM, defining it as the digital representation of buildings which supports the parametric modeling of buildings, forms the information base that includes the geometric information of buildings, and simulates the behavior of buildings [14]. As a digital tool, BIM can realize the information interaction and work cooperation of buildings throughout the whole lifecycle, from design, to construction, management, and maintenance [15]. It also provides an information sharing platform for all parties involved in a project [16]. In conclusion, BIM is a technical tool applied for the digital expression of the physical and functional representation of various infrastructures and a technical platform for resource information sharing. All stakeholders can provide support for the work of all parties through the input, modification, and retrieval of information [17].

Given the continuous maturation of BIM, it has been widely used in the main fields of the AEC industry. From the perspective of project lifecycle, in the planning and site selection stage BIM is used to combine the territorial planning, design, and site selection of buildings to ensure the rationality of construction [18]. The efficient combination of BIM and the design phase can help designers achieve multiple goals. In the design phase, BIM can effectively avoid rework problems caused by design errors and improve the delivery rate of the project [19]. At the same time, BIM can also be used as a collaborative design platform for information sharing to solve the interoperability of design software data of different disciplines problem for achieving real collaborative design [20]. BIM can not only make and control the construction schedule [21,22], but can also guide the specific construction technology operation. For example, BIM is used to guide the construction of formwork [23] and concrete pouring [24]. In addition, the 4D-BIM model can also be used for indoor construction monitoring [25]. The operation and maintenance of facilities is the last stage of the project lifecycle, and its effectiveness is affected by other stages of the project lifecycle. Based on the information sharing of BIM, the information of each stage of project design and construction can be integrated to improve the operation efficiency of facilities [26]. The operation and maintenance of the facility is also a continuous stage, which will produce a lot of data. Using the characteristics of BIM to store a lot of information can help managers to efficiently process the operation data and improve the performance of project operation and management [27]. Using BIM to manage and predict the process of building construction and demolition can effectively control the impact of construction and demolition waste on the environment and improve the sustainability of buildings [28,29]. At the same time, BIM has been widely used in green building evaluation [30], such as in the integration of Green Building Assessment Schemes (GBAS) and BIM [31]. Meanwhile, it also plays an active role in project progress management [32], the control of material cost [33], the guarantee of project quality [34], the control of project risk [35] and on-site safety management [16]. It is apparent that BIM can be applied to each stage in the entire lifecycle of various infrastructures, and it often has a positive impact on projects. Therefore, it is valuable to promote the sustainable development of BIM in the AEC industry; this also forms the significance of this paper, which explores the barriers to BIM application.

BIM technology has played an active role in all stages of the project lifecycle and has brought great convenience to project management. However, various barriers have been encountered in the process of promoting BIM application. This has already encouraged more people to research the identification, evaluation, and elimination of barriers in the development of BIM application. Fountain and Langar [36] studied the application of BIM in the United States; they found that various barriers hindered the full implementation of BIM. In-depth research on the phenomenon of BIM outsourcing has shown that respondents believe that BIM outsourcing is less efficient than internal BIM implementation. Piroozfar et al. [37] studied the UK construction industry and found that Integrated Project Delivery (IPD) does help to overcome barriers to collaboration, improve the early participation 
of key participants, and increase assumptions about the level of trust among key stakeholders, in order to help remove barriers to BIM application. Charef et al. [38] assessed the gaps in BIM application barriers in $28 \mathrm{EU}$ countries, and found that there is a large gap in the level of BIM application among EU countries which may hinder cross-border projects and cooperation. Construction companies in Egypt are moving from CAD to BIM. At the same time, these companies face the challenge of using Building Energy Models (BEM) to meet energy-saving requirements. Khodeir and Nessim [39] have studied the current application status of BIM2BEM in the Egyptian construction market and analyzed related application barriers. In addition, scholars from New Zealand [40], Sweden [41], and other countries have analyzed the obstacles to the application of BIM in their countries. Many scholars have studied the BIM application barriers in China, a country that actively promotes the application of BIM. Liu et al. [42] combined this with the current research situation of China's construction industry and made an exploratory study on the obstacles to the application of BIM in China's construction industry. They pointed out that the lack of comprehensive evaluation on the use value of BIM, the absence of BIM professional software and government promotion, the imbalance in the business levels of construction enterprises, the difficulty of designers' conversion thinking, and the short of relevant standards in China are a series of factors restricting the development of BIM. Ji et al. [43] drew the conclusion, by establishing the game model between government and enterprise, that the government's economic policy prevents BIM from being popularized in China. Liu and Zhao [44] obtained 15 factors restricting the development of BIM in China through a questionnaire survey of construction industry personnel. Additionally, Sun and Wang [45] combined the theory of information asymmetry and game theory to analyze the interactive relationships between BIM development and the interest game of project owners and contractors, and pointed out that, because of the information asymmetry brought by $\mathrm{BIM}$, the conflict of interest between the project owner and the contractor is a major factor hindering its development. Li et al. [46] used a literature review, interviews, and a questionnaire survey to discuss the reasons for the slow promotion of BIM in China from perspectives of the project owner, designer, and contractor, and found that the main barriers to BIM promotion are the owners' limited understanding of BIM, the designers' focus on the uncertainty of return on technology investment, and the contractors' anxiety about changing their operation mode. Zhou et al. [7] discovered six barriers to the implementation of BIM strategy in China from survey results: insufficient government leadership, organizational issues, legal issues, high application cost, resistance to the transformation of thinking mode, and insufficient external incentives. Zhang et al. [17] using factor analysis, exploratory factor analysis, and a structural equation model, found that the application barriers to BIM technology in sustainability projects mainly include public participation, technology application, economic cost, and application management, and pointed out that public participation is particularly important. Dong et al. [47] used the Decision-Making Test and Evaluation Laboratory method (DEMATEL) to discuss the application barriers and improvement measures for BIM in project cost, and pointed out the lack of policy support from government and industry authorities has the greatest impact on the other factors, and the support of senior management has become the direct cause of the promotion of BIM.

It is apparent that these barriers greatly hinder the development and application of BIM technology. To some extent, this has caused great losses to some engineering projects. Additionally, most of the existing studies use a literature review and questionnaire survey to explore the barriers to BIM-some of these studies are shown in Table 1. The existing research mainly identifies the existing barriers, while there is a lack of research on the relationships between, and influences among, these barriers. Compared with previous studies, this paper explores the barriers to BIM from a new perspective combined with effective research methods. Firstly, the barriers to BIM application in the current construction industry are comprehensively sorted out by literature analysis and expert interviews. Secondly, on the basis of exploring what the barriers to BIM application are, an in-depth study was implemented on the interactions among barrier factors. Finally, complex network theory is used to analyze the main barriers and put forward suggestions to control and eliminate BIM barriers from the 
perspective of the overall network. The research of this paper will further promote the application and development of BIM.

Table 1. Analysis of some references.

\begin{tabular}{|c|c|c|c|c|}
\hline Reference & $\begin{array}{l}\text { Country or } \\
\text { Region }\end{array}$ & Research Topics & Research Method & Main Contribution \\
\hline Olawumi et al. [48] & $\begin{array}{l}\text { US, China, } \\
\text { UK }\end{array}$ & $\begin{array}{l}\text { Explore the barriers faced by } \\
\text { construction stakeholders in } \\
\text { their attempts to integrate } \\
\text { BIM and sustainability } \\
\text { practices in the construction } \\
\text { processes }\end{array}$ & $\begin{array}{l}\text { Literature review, Delphi } \\
\text { survey }\end{array}$ & $\begin{array}{l}\text { Three major barriers to BIM } \\
\text { application were identified } \\
\text { through two rounds of Delphi } \\
\text { survey }\end{array}$ \\
\hline $\begin{array}{l}\text { Fountain and } \\
\text { Langar [36] }\end{array}$ & US & $\begin{array}{l}\text { Identify the BIM } \\
\text { outsourcing patterns and } \\
\text { perceive their impacts }\end{array}$ & Questionnaire survey & $\begin{array}{l}\text { Identified the three most common } \\
\text { BIM outsourcing functions; } \\
\text { obtained three driving factors and } \\
\text { four obstacles to contractor BIM } \\
\text { outsourcing }\end{array}$ \\
\hline Piroozfar et al. [37] & UK & $\begin{array}{l}\text { Explore whether and how } \\
\text { IPD can promote the } \\
\text { implementation of BIM in } \\
\text { the UK }\end{array}$ & $\begin{array}{l}\text { Questionnaire survey; } \\
\text { Relativist ontological }\end{array}$ & $\begin{array}{c}\text { In the UK, IPD can promote better } \\
\text { and wider application of BIM } \\
\text { Construction business }\end{array}$ \\
\hline $\begin{array}{l}\text { Khodeir and } \\
\text { Nessim [39] }\end{array}$ & Egypt & $\begin{array}{l}\text { Research on the application } \\
\text { of BIM and BEM in Egypt }\end{array}$ & $\begin{array}{l}\text { Semi-structured } \\
\text { questionnaire; } \\
\text { Case studies }\end{array}$ & $\begin{array}{l}\text { Obtained three driving factors } \\
\text { and three obstacles for BIM in } \\
\text { Egypt; suggestions for adopting } \\
\text { BIM2BEM integrated method }\end{array}$ \\
\hline Mehran [49] & UAE & $\begin{array}{l}\text { Explore the barriers to BIM } \\
\text { implementation in the UAE } \\
\text { and give some suggestions } \\
\text { to promote the development } \\
\text { of BIM }\end{array}$ & Questionnaire survey & $\begin{array}{l}\text { Found that the main obstacles to } \\
\text { BIM implementation in the UAE } \\
\text { are a lack of BIM standards and } \\
\text { understanding of BIM's } \\
\text { advantages, costs, and } \\
\text { profitability }\end{array}$ \\
\hline Kim et al. [50] & North Korea & BIM Acceptance Degree & $\begin{array}{l}\text { Questionnaire survey; } \\
\text { Structural } \\
\text { equation modeling }\end{array}$ & $\begin{array}{l}\text { Although AEC participants are } \\
\text { generally positive about BIM } \\
\text { application, factors such as } \\
\text { concerns about the effects of BIM } \\
\text { applications and conflicts with } \\
\text { existing processes have led to } \\
\text { differences in AEC participants' } \\
\text { attitudes towards BIM } \\
\text { applications }\end{array}$ \\
\hline $\begin{array}{l}\text { Abbasianjahromi } \\
\text { et al. [51] }\end{array}$ & Iran & $\begin{array}{l}\text { Assess the maturity and } \\
\text { readiness of consultants to } \\
\text { implement BIM }\end{array}$ & $\begin{array}{l}\text { Questionnaire survey; } \\
\text { Statistical analysis }\end{array}$ & $\begin{array}{l}\text { A maturity evaluation framework } \\
\text { for consulting firms was identified. } \\
\text { The framework has three main } \\
\text { steps, including finding obstacles, } \\
\text { weighting obstacles, and maturity } \\
\text { assessments }\end{array}$ \\
\hline Liao and Teo [52] & Singapore & $\begin{array}{l}\text { Discover key success factors } \\
\text { to improve BIM } \\
\text { implementation }\end{array}$ & $\begin{array}{l}\text { Literature review; } \\
\text { Questionnaire survey; } \\
\text { Factor analysis; } \\
\text { Structural equation } \\
\text { modeling }\end{array}$ & $\begin{array}{l}\text { Thirty-two success factors were } \\
\text { identified through literature } \\
\text { review and questionnaire survey, } \\
15 \text { key success factors were } \\
\text { identified through factor analysis, } \\
\text { and the relationships between } \\
\text { variables were analyzed through a } \\
\text { structural equation modeling }\end{array}$ \\
\hline Ma et al. [53] & China & $\begin{array}{l}\text { Determine the influencing } \\
\text { factors and their hierarchical } \\
\text { relationships, and finally } \\
\text { perform factor classification }\end{array}$ & $\begin{array}{l}\text { Literature review; } \\
\text { Questionnaire } \\
\text { survey; Interpretive } \\
\text { structural model; Impact } \\
\text { Matrix Cross-Reference } \\
\text { Multiplication Applied } \\
\text { to a Classification }\end{array}$ & $\begin{array}{l}\text { Identified } 21 \text { factors and their } \\
\text { hierarchical relationships and } \\
\text { performed factor classification }\end{array}$ \\
\hline Liu et al. [54] & China & $\begin{array}{l}\text { Define BIM user satisfaction } \\
\text { and analyze its influencing } \\
\text { factors }\end{array}$ & $\begin{array}{l}\text { Questionnaire survey; } \\
\text { Structural } \\
\text { equation modeling }\end{array}$ & $\begin{array}{l}\text { Information quality, senior } \\
\text { management support and } \\
\text { management by objectives are the } \\
\text { key factors affecting the } \\
\text { satisfaction of BIM users in } \\
\text { construction projects }\end{array}$ \\
\hline
\end{tabular}




\section{Methodology}

\subsection{Analytical Framework}

As described above, a literature review was carried out to establish a strong foundation for this research and support the development of the overall research framework. According to the research objective, a new and detailed framework is proposed and described in Figure 1. This research process can be divided into three steps. The first step was data collection, which consisted of three substeps. There were two ways to obtain the barrier factors for BIM application. One was to collect the barrier factors in the related literature through literature analysis, and the other was to identify the new barrier factors from the expert interviews based on grounded theory. After that, the Delphi method was used to determine the interactions among the determined barriers. The second step was to use complex network theory to establish a BIM application barrier network (BABN). The third step was to use some characteristics of complex network theory to analyze the network model. This paper then summarizes the research results and gives suggestions to promote the development of BIM application in China.

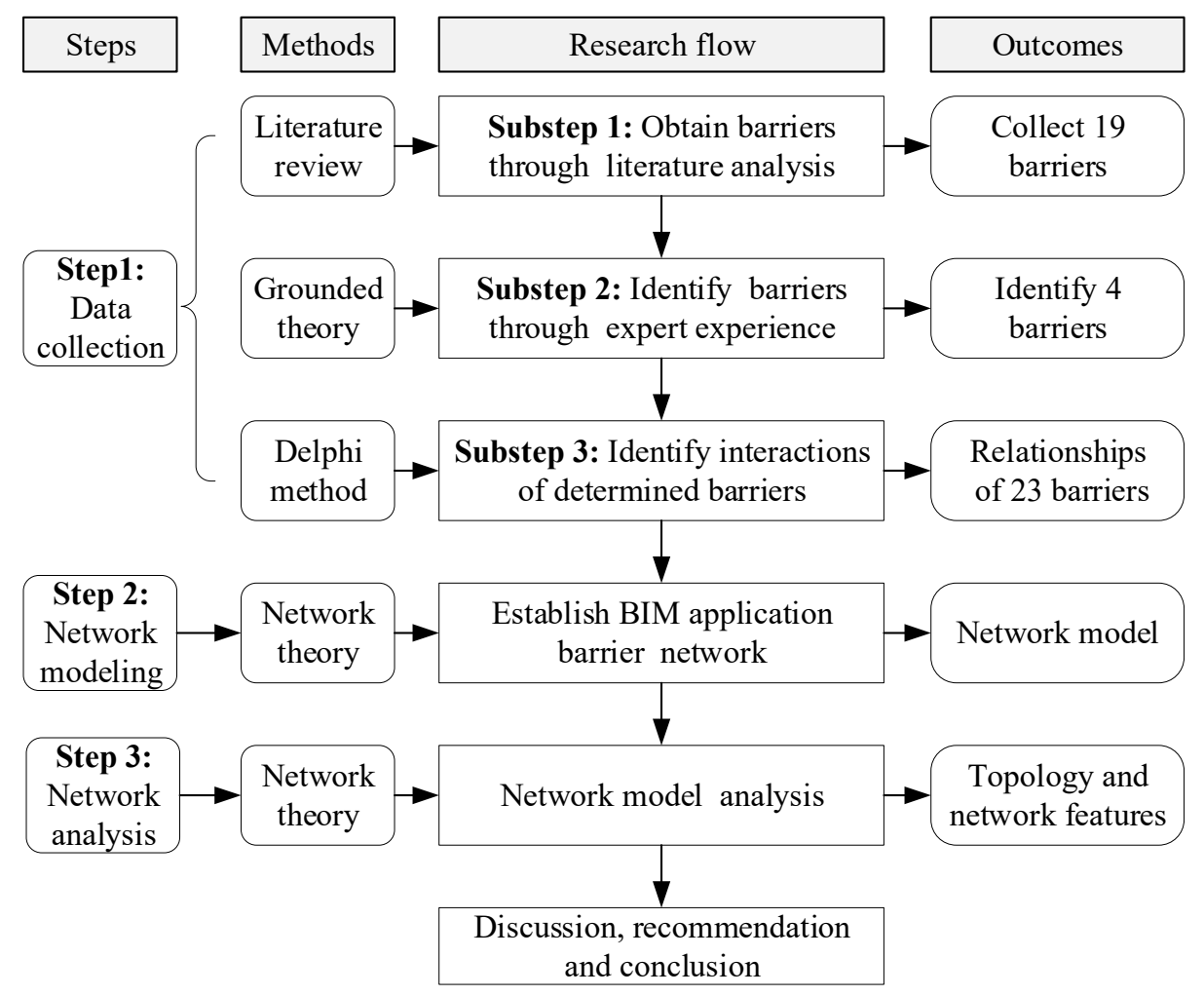

Figure 1. The analytical framework.

\subsection{Data Collection and Analysis}

First, relevant literature was searched in the Web of Science (WoS) and the China National Knowledge Infrastructure (CNKI). Second, in-depth interviews were implemented. The respondents have had at least of three years of BIM work experience, including as owners, designers, contractors, etc. The interviews were about the current situation and BIM application barriers in China's AEC industry. Grounded theory was employed to analyze the content of the interviews and find new the BIM application barriers obtained in the interview. Then, all the barriers were summarized. Finally, the interactions among the barriers were determined through the Delphi method, and then a network model was established and analyzed based on complex network theory.

Three methods were employed for data collection in this study, including a literature review, grounded theory, and the Delphi method. The whole process consisted of three stages. In the first 
stage, Boolean operations were used to search the Web of Science and the China National Knowledge Infrastructure with the keywords ((BIM or (Building Information Model) or (Building information modeling) or (building information modeling)) and (obstacle or barrier)). The search results were refined to find articles describing the Chinese market. In the second stage, expert interviews were implemented based on grounded theory. In order to fill the gap in the literature analysis and search for new barriers to BIM application, an expert interview was conducted. Before the formal interview, the interviewers first communicated with the experts on the barriers to BIM application collected in the literature, and then the in-depth interviews were carried out based on questions prepared in advance. The interview time for each expert lasted between 30 minutes and 1 hour. The content of the interviews was analyzed using grounded theory to obtain new BIM application barriers. In the third stage, the relationships between BIM application barriers were obtained through two rounds of the Delphi method.

\subsection{Grounded Theory}

Grounded theory, which was initially established by Glaser and Strauss [55], is a qualitative methodology to inductively generate theory. It emphasizes the generation of pragmatic theory that is grounded in the data of experience, which has resulted in its profound and enduring impact in qualitative research [56]. Grounded theory has been widely recognized and applied in many fields since it was put forward, including medical sociology, nursing, education, and management theory [57]. Li et al. [58] have revealed the driving factors of green development behavior and the performance in industrial enterprises based on the grounded theory. By using a grounded theory approach, Liu et al. [59] analyzed the qualitative data to explore project professionals' understandings of BIM application in collaborative design and construction.

The main implementation steps of grounded theory are illustrated in Figure 2. Based on the bottom-up research process, researchers gained information from investigation; then, open coding, axial coding, selective coding, and theoretical saturation test were sequentially performed. In this process, coding refers to the continuous comparison between events and concepts, so as to facilitate the conceptualization of data. Theoretical saturation refers to the point at which the data and information extracted by the sample are saturated. Once the saturation test was completed and verified, the theory will not be affected by the new sample [60].

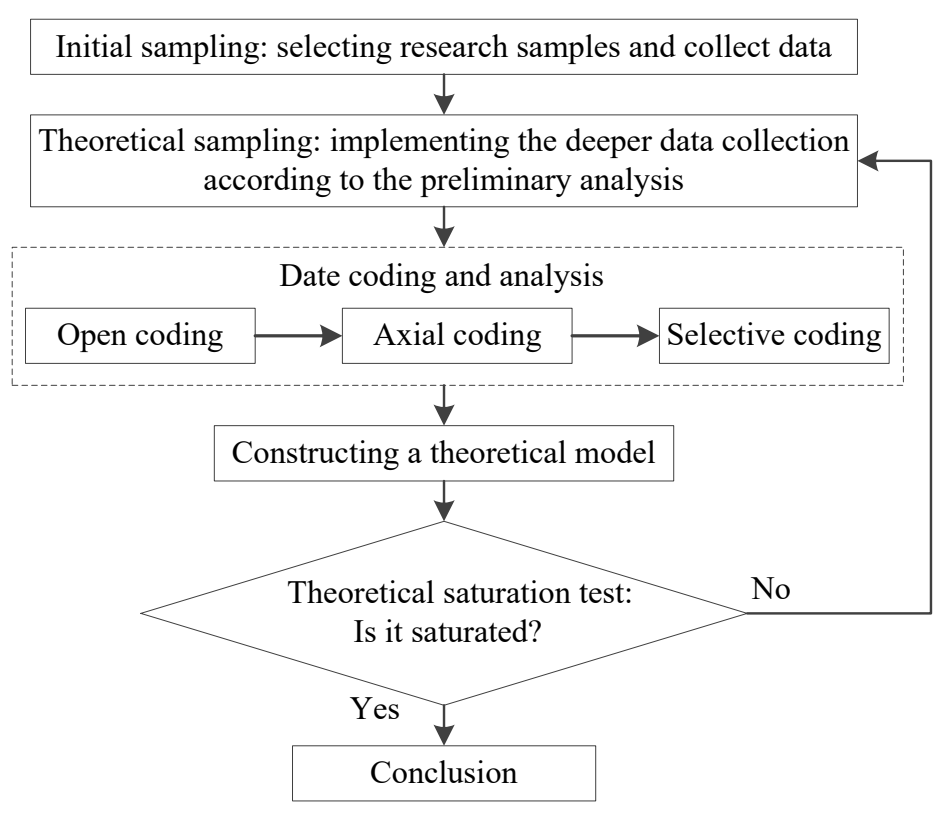

Figure 2. The implementation steps for grounded theory. 


\subsection{The Delphi Method}

The Delphi method is a management decision tool for creating public policy, forecasting, and guiding industry that was proposed and developed by the RAND Corporation during the 1950s and 1960s [61,62]. It is a widely accepted and modifiable process for obtaining information characterized by semi-anonymity and iterative questionnaires [63]. The Delphi method works well when the opinions of relevant experts and stakeholders are needed and the empirical evidence is uncertain or lacking, and it has been demonstrated as a reliable method in many areas $[64,65]$. Those areas include ecological economics research to estimate the value of protecting the Amazon rainforest [66], environmental education to clarify the landscape and core outcomes [64], the construction industry to identify and prioritize the benefits of integrating BIM and sustainability practices in construction projects [48], and so on.

The process of the Delphi method is summarized as follows. The researchers designed a questionnaire after identifying a research problem and selected an appropriate group of qualified experts who are knowledgeable in the field. Then initial questionnaire, initial feedback, subsequent questionnaire, and subsequent feedback were executed in sequence. In the feedback stage, the questionnaire was modified according to the statistical analysis of the results in the previous round. This process was reiterated until a satisfactory degree of consensus was achieved $[61,65]$.

\subsection{Network Modeling and Analysis}

Currently, there exist many systems which can be regarded as complex systems, such as the supply chain system [67], vehicular traffic system [68] and the Internet [69]. During the late 1950s, Erdös and Rényi proposed the "random graph", which was a momentous achievement, but the description of some important characteristics of real-word network was inadequate. The small-world model, which has high clustering coefficients and small-world effect, was proposed by Watts and Strogat [70]. Then, Barabási and Albert revealed the scale-free properties of complex networks and established a corresponding model [71]. The study of complex networks has entered a new stage since then. It is pervading all fields of science, rather than being limiting to the category of mathematics.

The study of complex networks can be simply summarized into three aspects which are closely related and continuous deep. The first one aims to find the statistical properties of networks empirically and to measure them with the appropriate method. The second one aims to create models of networks which make it possible to understand their statistical properties. The third one aims to predict and affect the behaviors of networks $[7,72]$.

The network is composed of a set of vertexes abstracted from elements of the system and a set of edges that link the vertexes together. The edges represent the interaction between the two connected vertexes. For directed networks, the arrow reflects the direction of interaction of two vertexes at the two ends. Using this modeling approach, the BIM application barriers were abstracted as a directed network. In this network, the vertexes represented the BIM barrier factor and the edges represented the relationships between the two connected vertexes. The influence relationships among the barriers of BIM development and application were explored and analyzed based on the network model.

The statistical indexes of networks are the basis of the statistical description of various topological characteristics. In this study, several typical indexes were employed to explore and analyze the BABN, including degree distribution, betweenness, eigenvector, clustering coefficient, average path length, and network diameter. The degree of a vertex represented the number of edges connected to itself directly. Especially in a directed network, each vertex owns both in-degree and out-degree, which are the numbers of ingoing links and outgoing links, respectively. The total degree of a vertex was the sum of the in-degree and out-degree. The betweenness centrality of a vertex was the ratio of the number of the shortest paths between other vertexes that run through this vertex to the total number of shortest paths. It is a global measure of centrality. The eigenvector centrality of a vertex was the degree of connection with the vertexes with high eigenvector centrality. The clustering coefficient of a vertex was defined as the ratio of the actual number of edges to the total number of potential edges which are 
between neighbors. The clustering coefficient of the network was defined as the arithmetic mean of the clustering coefficients of all vertexes. The diameter of a network was the number of edges of the longest path between any two vertexes. The path length of two vertexes was the number of edges of the shortest path between two vertexes. Furthermore, the average path length was defined as the average number of path length for all possible pairs of vertexes in a network.

Pajek is a program package for the analysis and visualization of large networks running on Windows. In addition to being used as a purely visualization tool for displaying any kind of networks, Pajek has several application areas, including the analysis of any kind of social networks, citation and co-authorship networks, protein-protein interaction networks, transportation networks, archaeological networks, and so on [73].

\section{Results}

\subsection{Data Collection}

\subsubsection{Data from the Literature Review}

It was necessary to screen the literature to find papers that analyze China's BIM development in the search results. In order to ensure the comprehensiveness of the literature, various expressions were considered as much as possible when searching the literature. Applying the aforementioned retrieval method, 18 English articles and 20 Chinese articles about BIM application barriers were retrieved and screened; relevant literature was searched by the WoS and CNKI. According to these 38 articles, 19 barriers were summarized, as shown in Table 2.

Table 2. BIM application barriers obtained from the literature review.

\begin{tabular}{|c|c|c|}
\hline Code & Barrier & Key References \\
\hline B01 & Domestic BIM software does not meet the actual work requirements & {$[7,11,12,17,42,44,46,48,53,74-87]$} \\
\hline B02 & Lack of proper workflow for BIM application & {$[17,42,45,75,79-84,88]$} \\
\hline B03 & $\begin{array}{l}\text { Compared with the previous working mode, using BIM increases } \\
\text { the workload }\end{array}$ & {$[12,44,45,75,77]$} \\
\hline B04 & Lack of time and energy to learn BIM & {$[84,86,88]$} \\
\hline B05 & Leaders at the corporate level lack long-term vision and confidence & {$[54,80,81,84,87-90]$} \\
\hline B06 & $\begin{array}{l}\text { Under the multi-contractor mode, all parties are unwilling to share } \\
\text { information and work together }\end{array}$ & {$[12,17,42,44,45,54,75-78,80-82,90,91]$} \\
\hline B07 & Misunderstanding of BIM concept & {$[12,44,77,80,81,83,84,87,90,92]$} \\
\hline B08 & Lack of BIM talents & {$[42,44,53,75,76,80-82,91]$} \\
\hline B09 & Unclear objectives for BIM application & {$[77,90,93]$} \\
\hline $\mathrm{B} 10$ & $\begin{array}{l}\text { Insufficient government guidance (lack of relevant laws } \\
\text { and standards) }\end{array}$ & {$[12,17,42,44,53,54,75-78,80,81,89-92]$} \\
\hline B11 & Inadequate customer and market demand & {$[12,42,44,75,77,78,80,83,85,87-94]$} \\
\hline B12 & $\begin{array}{l}\text { Companies that use BIM successfully are reluctant to } \\
\text { share experiences }\end{array}$ & {$[76,90,94]$} \\
\hline B13 & Lack of systematic BIM learning resources & {$[17,45,54,87,89,90,94]$} \\
\hline B14 & High initial economic cost for the use of BIM technology & {$[12,17,44,75-77]$} \\
\hline B15 & The benefits of BIM application are difficult to evaluate & {$[12,44,54,76-78,80,82,94]$} \\
\hline B16 & The holder of economic cost caused by BIM technology is not clear & {$[7,11,80,89]$} \\
\hline B17 & Lack of BIM standards in line with market demand & {$[12,17,53,54,76-82,87,89-92]$} \\
\hline B18 & Lack of a standard form of contract for BIM application & {$[42,44,45,54,75-78,80,81,84,87,89,90,92]$} \\
\hline B19 & Lack of insurance applicable to BIM application & {$[12,42,45,75,77,82,90]$} \\
\hline
\end{tabular}

\subsubsection{Data from the Expert Interviews}

A total of 31 experts with rich BIM work experience were interviewed. The data obtained from the expert interviews was analyzed based on grounded theory. First, 25 samples were randomly selected from all the interview samples for open coding; the other 6 samples were used as theoretical saturation tests. Open coding is the process of comparing and analyzing the source material verbatim, giving a conceptual label, and then summarizing it to discover new barriers to BIM application. Finally, 627 original sentences and concepts were obtained according to open coding. The concepts that appeared less than three times were deleted, and 592 concepts were determined at last. Excerpt from 
the open coding process are illustrated in Table 3. Among them, A1-3 represent the third coding concept of the first respondent in the face-to-face interview. A total of four new BIM application barriers were passed through open coding: project-level managers are reluctant to risk using BIM, the lack of reasonable performance evaluation standards in enterprises, the long payback period for building BIM team, and the BIM consulting market is chaotic. Second, the 23 BIM application barriers were classified by spindle coding, and they were divided into technical, management, environment, economic, and legal, as shown in Table 4. Third, in using grounded theory to analyze the six samples reserved, no new concepts and categories were discovered, indicating that BIM application barriers have reached saturation.

Table 3. Open coding process (excerpt).

\begin{tabular}{|c|c|c|}
\hline Code & Barrier & Original Statement (Initial Concept) \\
\hline B20 & $\begin{array}{l}\text { Project-level managers are } \\
\text { reluctant to risk using BIM }\end{array}$ & $\begin{array}{l}\text { A1-3. Because the performance evaluation of the project-level } \\
\text { managers is progress, quality, cost, or the achievement of other } \\
\text { project goals, not the use of BIM. They prefer to use the } \\
\text { traditional, more familiar project management model, which } \\
\text { will reduce the risk of their project failure. }\end{array}$ \\
\hline B21 & $\begin{array}{c}\text { Lack of reasonable performance } \\
\text { evaluation standards in } \\
\text { enterprises }\end{array}$ & $\begin{array}{l}\text { A7-10. For designers, using BIM to design a project takes more } \\
\text { time than using computer aided design (CAD). The design unit } \\
\text { calculates performance pay based on the number of projects } \\
\text { done, which causes designers to be reluctant to use BIM. } \\
\text { A10-3. There are only a few people responsible for BIM on } \\
\text { many construction units. If they devote all their energy to this } \\
\text { model, update, and maintenance, there will be a problem. } \\
\text { They do not create any output value, but an important } \\
\text { performance evaluation standard for construction units is } \\
\text { output value. }\end{array}$ \\
\hline B22 & $\begin{array}{l}\text { Long payback period for building } \\
\text { BIM team }\end{array}$ & $\begin{array}{l}\text { A14-13. At present, only large design institutes in the market } \\
\text { could organize their own BIM teams. Because organizing a } \\
\text { professional BIM team requires a relatively long return on } \\
\text { investment, small- and medium-sized design institutes do not } \\
\text { have the strength to support it. }\end{array}$ \\
\hline B23 & BIM consulting market is chaotic & $\begin{array}{l}\text { A20-4. At present, there is no good evaluation system to } \\
\text { evaluate BIM consulting companies, which makes it difficult } \\
\text { for owners to judge the level of BIM consulting companies } \\
\text { when bidding. Some poorly-skilled BIM consulting companies } \\
\text { often disrupt the market at low prices in order to win bids, } \\
\text { which makes it difficult for well-skilled BIM consulting } \\
\text { companies to survive. Their lower technical level will cause } \\
\text { the failure of a project's BIM application, which will also make } \\
\text { the owner no longer willing to use BIM. }\end{array}$ \\
\hline
\end{tabular}

Table 4. The determined barriers.

\begin{tabular}{cc}
\hline Category & Barrier Code \\
\hline Technical & B01, B02, B03, B04 \\
Management & B05, B06, B07, B08, B09, B20, B21 \\
Environment & B10, B11, B12, B13, B23 \\
Financial & B14, B15, B16, B22 \\
Legal & B17, B18, B19 \\
\hline
\end{tabular}

\subsubsection{Determining the Relationships between Barriers through the Delphi Method}

The Delphi method was employed to explore the influence interrelationships among the identified 23 barriers. According to Hallowell and Gambatese [95], the proper number of the Delphi panel would be 8 to 12 members. Therefore, 11 experts with rich experience were selected to determine the interrelationships among the BIM application barriers. The results are shown in Table 5 . This matrix consists of 23 rows and 23 columns. In the matrix, the value of 1 indicates that the barrier in the row has influence on the barriers in the column, and 0 means no relationship. For example, the 1 in the first row and the third column means B01 has influence on B03. 
Table 5. The barriers relationships matrix.

\begin{tabular}{|c|c|c|c|c|c|c|c|c|c|c|c|c|c|c|c|c|c|c|c|c|c|c|c|}
\hline & B01 & B02 & B03 & B04 & B05 & B06 & B07 & B08 & B09 & B10 & B11 & B12 & B13 & B14 & B15 & B16 & B17 & B18 & B19 & B20 & B21 & B22 & B23 \\
\hline B01 & - & 0 & 1 & 0 & 0 & 0 & 0 & 0 & 1 & 0 & 1 & 0 & 0 & 0 & 1 & 0 & 0 & 0 & 0 & 1 & 0 & 1 & 1 \\
\hline B02 & 0 & - & 1 & 0 & 1 & 1 & 0 & 0 & 1 & 0 & 0 & 0 & 0 & 0 & 1 & 0 & 0 & 0 & 0 & 0 & 1 & 0 & 0 \\
\hline B03 & 0 & 0 & - & 1 & 0 & 0 & 0 & 1 & 0 & 0 & 0 & 0 & 0 & 1 & 1 & 1 & 0 & 0 & 0 & 1 & 1 & 0 & 0 \\
\hline B04 & 0 & 0 & 0 & - & 0 & 0 & 1 & 1 & 0 & 0 & 0 & 0 & 0 & 0 & 0 & 0 & 0 & 0 & 0 & 1 & 0 & 0 & 0 \\
\hline B05 & 0 & 1 & 0 & 0 & - & 1 & 0 & 1 & 1 & 0 & 1 & 0 & 0 & 0 & 0 & 0 & 0 & 0 & 0 & 1 & 1 & 0 & 0 \\
\hline B06 & 0 & 1 & 1 & 0 & 0 & - & 0 & 0 & 0 & 0 & 0 & 0 & 0 & 0 & 0 & 0 & 0 & 0 & 0 & 1 & 0 & 0 & 0 \\
\hline B07 & 0 & 1 & 0 & 0 & 1 & 0 & - & 0 & 1 & 0 & 1 & 0 & 0 & 0 & 1 & 1 & 0 & 0 & 0 & 1 & 1 & 1 & 0 \\
\hline B08 & 1 & 1 & 0 & 0 & 0 & 0 & 0 & - & 1 & 1 & 0 & 0 & 0 & 1 & 0 & 0 & 0 & 0 & 0 & 1 & 1 & 0 & 1 \\
\hline B09 & 0 & 1 & 0 & 0 & 1 & 0 & 0 & 1 & - & 1 & 1 & 0 & 0 & 0 & 1 & 1 & 1 & 1 & 0 & 1 & 1 & 0 & 0 \\
\hline B10 & 1 & 1 & 0 & 0 & 1 & 1 & 0 & 1 & 0 & - & 1 & 1 & 1 & 1 & 0 & 1 & 1 & 1 & 1 & 1 & 1 & 0 & 1 \\
\hline B11 & 1 & 0 & 0 & 1 & 1 & 0 & 0 & 1 & 0 & 0 & - & 0 & 0 & 1 & 0 & 0 & 1 & 1 & 1 & 1 & 0 & 1 & 0 \\
\hline$\overline{\mathrm{B} 12}$ & 0 & 1 & 0 & 0 & 0 & 0 & 0 & 1 & 1 & 0 & 0 & - & 1 & 1 & 1 & 0 & 1 & 1 & 1 & 1 & 1 & 1 & 1 \\
\hline B13 & 0 & 0 & 0 & 0 & 0 & 0 & 1 & 1 & 0 & 0 & 0 & 1 & - & 1 & 0 & 0 & 0 & 0 & 0 & 0 & 0 & 1 & 1 \\
\hline B14 & 0 & 0 & 0 & 0 & 1 & 0 & 0 & 0 & 0 & 0 & 1 & 0 & 0 & - & 0 & 0 & 0 & 0 & 0 & 1 & 0 & 1 & 1 \\
\hline$\overline{\mathrm{B} 15}$ & 0 & 0 & 0 & 0 & 1 & 0 & 0 & 1 & 0 & 0 & 1 & 0 & 0 & 0 & - & 1 & 0 & 1 & 0 & 1 & 1 & 0 & 0 \\
\hline $\bar{B} 16$ & 0 & 0 & 0 & 0 & 1 & 1 & 0 & 0 & 0 & 0 & 1 & 1 & 0 & 1 & 1 & - & 0 & 1 & 1 & 1 & 0 & 1 & 0 \\
\hline B17 & 1 & 1 & 1 & 0 & 1 & 1 & 1 & 0 & 1 & 0 & 1 & 0 & 0 & 0 & 1 & 1 & - & 1 & 0 & 1 & 1 & 0 & 1 \\
\hline B18 & 0 & 1 & 0 & 0 & 1 & 1 & 0 & 0 & 1 & 0 & 1 & 0 & 0 & 0 & 1 & 1 & 0 & - & 1 & 1 & 1 & 0 & 1 \\
\hline$\overline{\text { B19 }}$ & 0 & 0 & 0 & 0 & 0 & 1 & 0 & 0 & 0 & 0 & 0 & 0 & 0 & 0 & 0 & 0 & 0 & 0 & - & 1 & 0 & 0 & 0 \\
\hline B20 & 0 & 1 & 0 & 1 & 0 & 1 & 0 & 1 & 0 & 0 & 0 & 0 & 0 & 0 & 1 & 1 & 0 & 0 & 0 & - & 1 & 0 & 0 \\
\hline B21 & 0 & 1 & 0 & 1 & 0 & 0 & 0 & 1 & 0 & 0 & 0 & 0 & 0 & 0 & 1 & 1 & 0 & 0 & 0 & 1 & - & 0 & 0 \\
\hline B22 & 0 & 0 & 0 & 0 & 1 & 0 & 0 & 1 & 0 & 0 & 1 & 0 & 0 & 1 & 1 & 0 & 0 & 0 & 0 & 1 & 0 & - & 0 \\
\hline B23 & 0 & 0 & 0 & 0 & 1 & 0 & 1 & 0 & 1 & 0 & 0 & 0 & 0 & 0 & 1 & 0 & 0 & 0 & 0 & 1 & 0 & 0 & - \\
\hline
\end{tabular}

Note: the value of 1 indicates that the barrier in the row has influence on the barriers in the column, and 0 means no relationship.

\subsection{Network Modeling}

From the perspective of complex networks, a total of 23 application barriers can be regarded as the vertexes, and their relationships can be regarded as the edges in BABN. According to Table 4, the network model can be established with Pajek software based on network theory, as shown in Figure 3. The network model consists of 23 vertexes and 178 edges. Correspondingly, in the BABN model, there is a line with an arrow from the vertex representing the barrier in the row to the vertex representing the barrier in the column. For example, the absence of a standard BIM contract template (vertex 18) can lead to the shortage of appropriate workflow for BIM implementation (vertex 2), and the value of the eighteenth row in the second column is 1. 


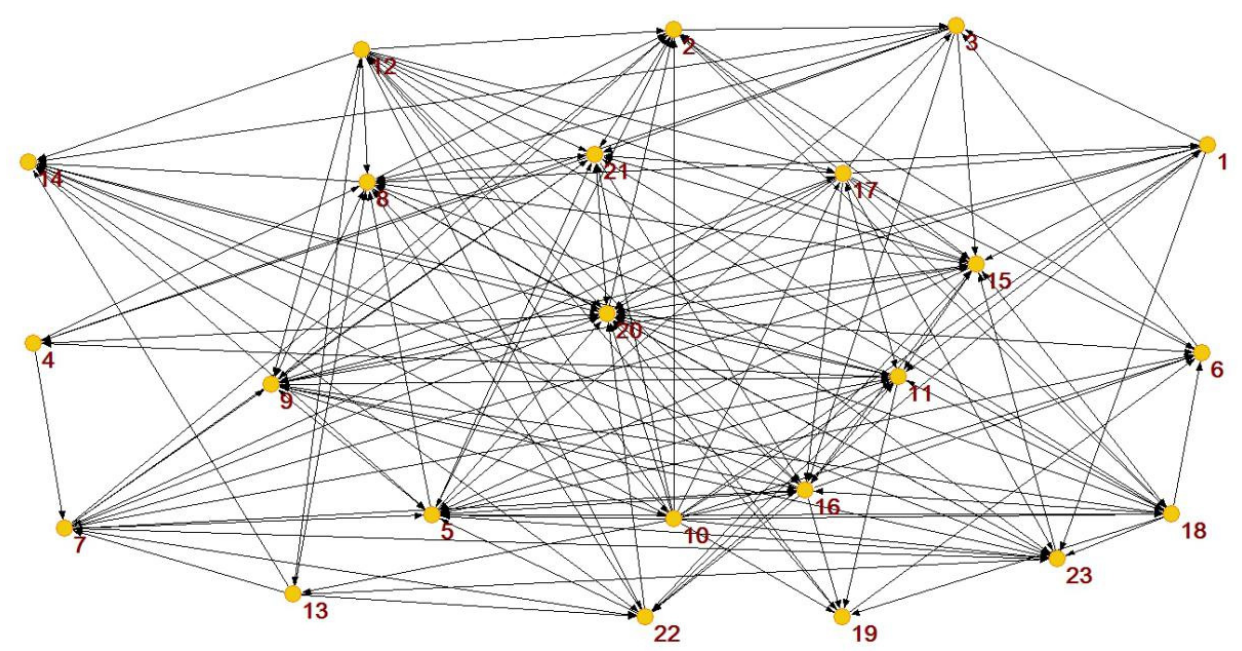

Note: The vertex with label represents the corresponding barrier factor, and the arrow represents the direction of the interaction of two vertexes.

Figure 3. The BIM application barrier network model.

\subsection{Network Analysis}

\subsubsection{Degree Distribution}

Degree distribution provides an indication of the immediate connectivity characteristics of a BIM application barrier. The in-degree refers to the direct impact on one barrier from the others and the out-degree refers to the direct impact from one barrier to the others. The degree distribution of all vertexes in BABN is shown in Figure 4. The barrier "project-level managers are reluctant to risk using BIM" (vertex 20) has the highest degree, 27, with a 20 in-degree and 7 out-degree, which indicates that it is in a relatively central position. Its in-degree is also the highest in the network, so it is more difficult to control compared to other factors. The barrier "the benefits of BIM application are difficult to evaluate" (vertex 15) has the next highest in-degree with a value of 13. "Insufficient government guidance (a lack of relevant laws and standards)" (vertex 10) has the highest out-degree with a value of 16, which means that this barrier has influence on 16 other barriers. This is a serious barrier in the development of BIM. In addition, the average degree of the network is 15.57, which indicates that each barrier connects with 15 or 16 other barriers in the entire network.

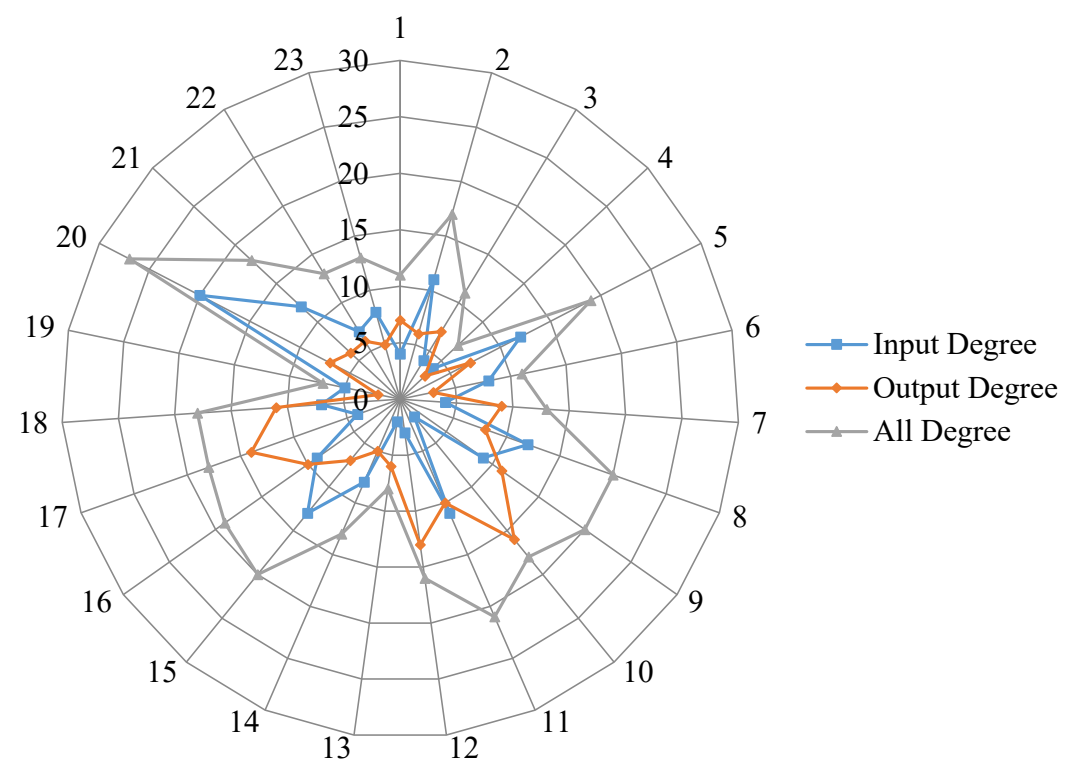

Figure 4. Degree distribution. 


\subsubsection{Betweenness Centrality}

The betweenness of a vertex shows the ability to control the interactions or influences flowing through it, and the higher the value of vertex betweenness, the stronger the ability [96]. The values of vertex betweenness centrality range from 0.0001 to 0.117 , as illustrated in Figure 5 . The "lack of BIM talents" (vertex 8), "project-level managers are reluctant to risk using BIM" (vertex 20) and the "holder of economic cost caused by BIM technology is not clear" (vertex 16) are the top three vertexes with the largest values of $0.1170,0.1158$, and 0.0998 , respectively. This indicates that these three are the most influential barriers in the BABN and cause the largest increase in typical distance between other factors when they are solved [97]. Therefore, the effective control and resolution of these barriers should be paid more attention in order to reduce the BABN chain reaction.

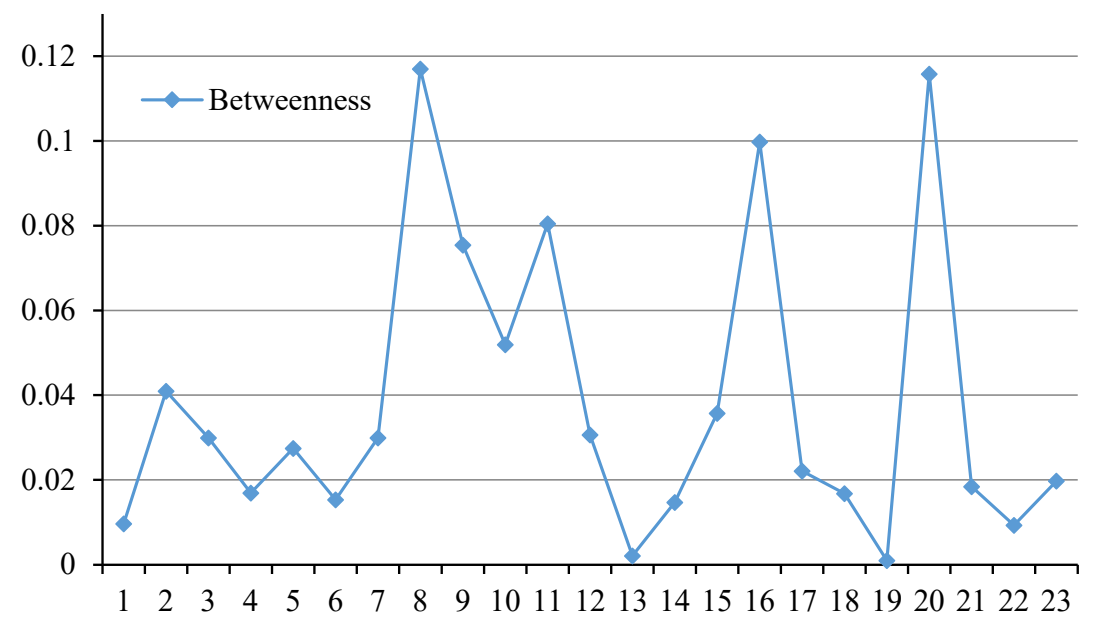

Figure 5. Values of vertex betweenness.

\subsubsection{Eigenvector Centrality}

Unlike degree distribution and betweenness centrality, eigenvector centrality identifies how the BIM application barriers relate with important ones but may not matter in itself [98]. The eigenvector centrality of all vertexes in the BABN is shown in Figure 6. "Leaders at the corporate level lack long-term vision and confidence" (vertex 5), "the lack of BIM standards in line with market demand" (vertex 17) and "the lack of a standard form of contract for BIM application" (vertex 18) are three vertexes with a high eigenvector centrality but low betweenness comparatively.

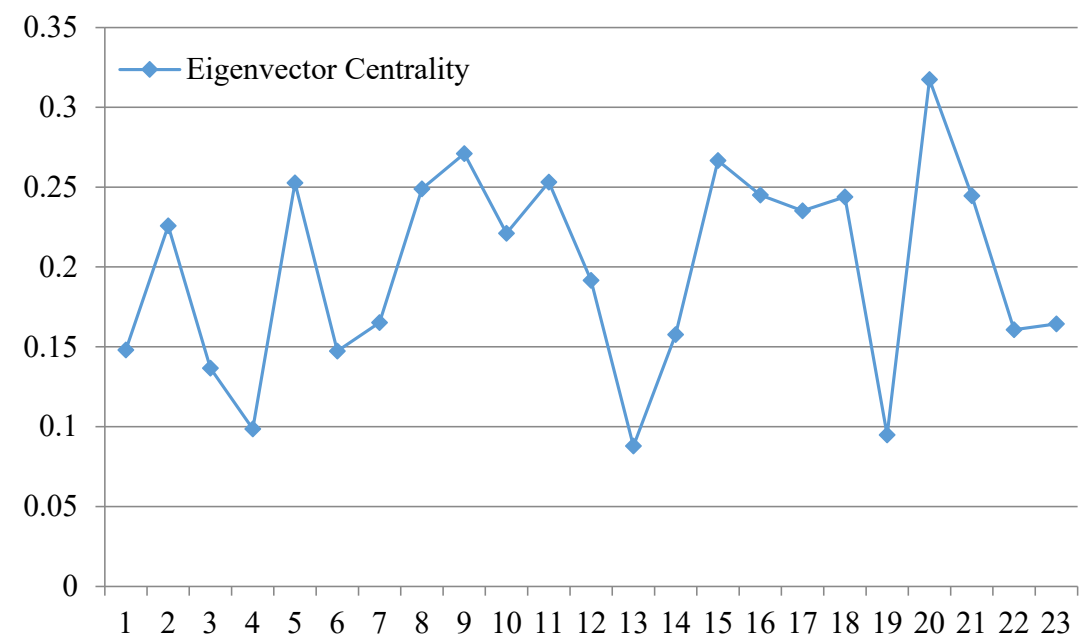

Figure 6. Values of eigenvector centrality. 


\subsubsection{Clustering Coefficient}

The vertex clustering coefficient of the BABN is shown in Figure 7. The highest clustering coefficient is 0.5238 (vertex 19) and the lowest is 0.3429 (vertex 20). The value of the clustering coefficient of the whole network is 0.4033 . The large clustering coefficient denotes that the BABN has a high degree of cliquishness.

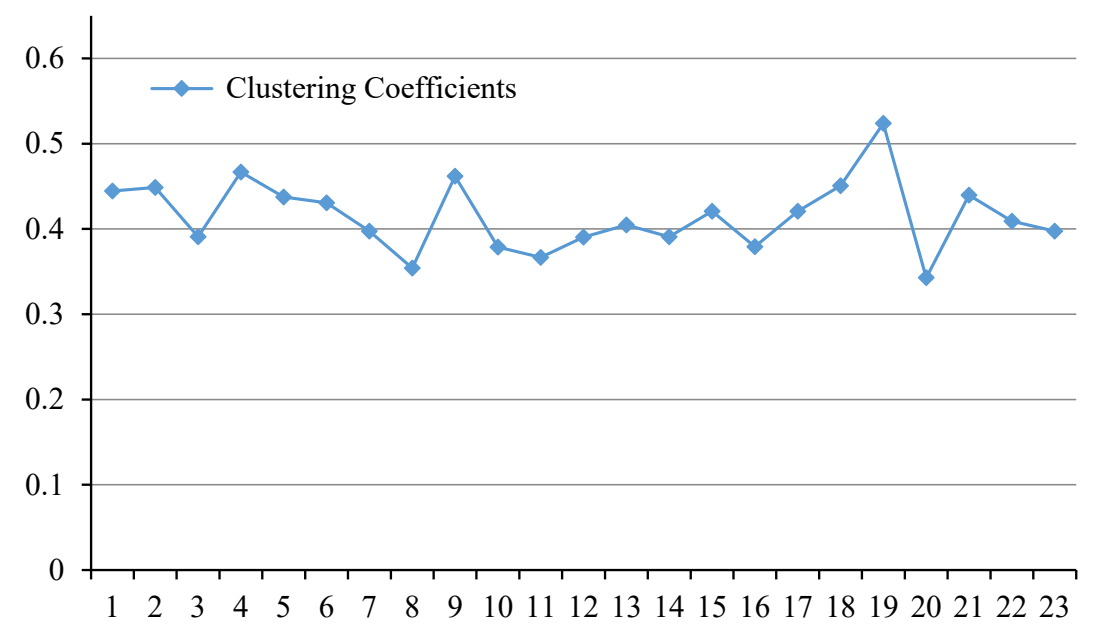

Figure 7. Values of clustering coefficient.

\subsubsection{Network Diameter and Average Path Length}

The network diameter in the BABN is 4 , which is from that "all parties that are unwilling to share information and work together under the multi-contractor mode" (vertex 6) to "the lack of systematic BIM learning resources" (vertex 13). One of the corresponding paths is as follows: "all parties are unwilling to share information and work together under the multi contractor mode" (vertex 6), "the shortage of appropriate workflow for BIM implementation" (vertex 2), "unclear objectives for BIM application" (vertex 9), "insufficient government guidance (lack of relevant laws and standards)" (vertex 10) and "the lack of systematic learning resources for BIM" (vertex 13). In the BABN, the average path length is 1.8044, indicating that a barrier can influence another only in one or two steps on average. Barrier factors are relatively tightly coupled in the BABN.

\subsubsection{The Small-World Property}

A small-world network is a special kind of graph with high transitivity in which most vertexes can be reached from every other by a small number of steps. According to Sections 4.3.3 and 4.3.4, it is acknowledged that the average path length and clustering coefficient of the BABN are 1.80435 and 0.4033 , respectively. The BABN has a short average path length and a high clustering coefficient, which indicates that it has small-world characteristics. Hence it is of great significance to control the connection between application barriers to avoid creating a worse situation under the condition of an occurred barrier factors.

\subsubsection{The Scale-Free Property}

Besides small-world property, the scale-free property is another feature which has been observed in a number of real networks. The degree distribution of such networks satisfies power-law decay. The cumulative $P(k)$ of the BABN is depicted in Figure 8 with the approximate fit $P(k)=2.2283 \times k^{-1.021}$, which basically follows the power-law. Therefore, according to the complex network theory, the BABN has the characteristics of a scale-free network, including being robust to random risks to some extent and being vulnerable to simultaneous attacks aiming at vertexes with a high degree. It is more effective to take measures to address the barrier factors represented by vertexes with a high degree. 


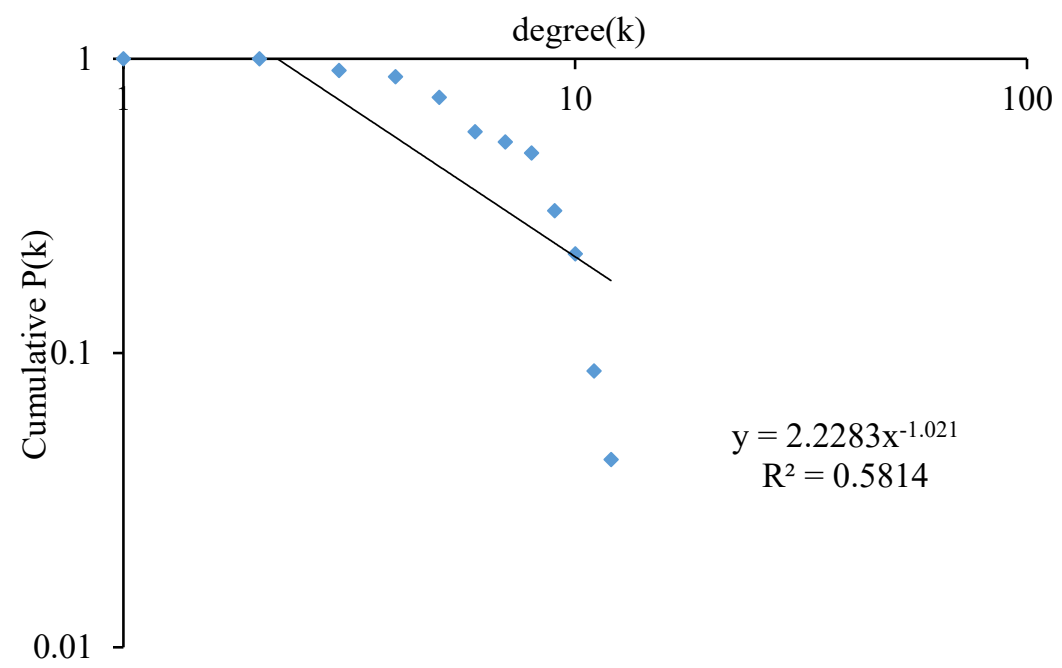

Figure 8. Calculative degree distribution of the BIM application barrier network.

\section{Discussion and Recommendation}

$\mathrm{BIM}$, as an emerging technology in the AEC industry, faces various barriers in its development and application. In order to promote BIM development and application, this study has identified and analyzed the barriers to BIM application. In this study, an analytical framework was proposed to promote the development and application of BIM, which seems to be effective and feasible. By using a literature review and expert interview, 23 BIM application barriers were identified, and the interactions of these barriers was determined. The BABN was established as an unweighted directed network model consisting of 23 vertexes and 178 edges. The main topological characteristics and network features of the BABN were identified and analyzed based on complex network theory.

The potential contribution of this research includes three aspects. First, it is conducive to understanding the complexity of barriers to the application of BIM technology. Second, stakeholders can develop coping strategies to promote BIM development by controlling the original barriers and avoiding derivative incidents based on the recognized interactions of BIM application barriers. Third, the research results have the potential benefits for generating necessary and scientific policies that can enhance the BIM application level.

The research methods adopted in this study were suitable and effective. The advantages of applying grounded theory included two aspects. On the one hand, the BIM application barriers were summarized from enough original materials, and the barriers of BIM application in China at the present stage were supplemented and enriched through interviews. On the other hand, the integrity of the results was guaranteed through saturation test. Meanwhile, the potential advantages of applying network analysis included two aspects. First, it takes all the barriers and their interactions into consideration in a network model. Second, the topological characteristics and network features were quantitatively calculated. In addition, the main limitation of this study was that the BABN fails to take the vertex weight into consideration. In fact, it was very difficult to discern and determine the different importance for different barriers. Hence, assigning the barrier weight was quite difficult. That may explain why BABN is an unweighted network model. In a future study, more attention should be paid to improve the network model based on a more precise understanding of BIM application barriers.

According to the results, the important barriers should be selected prior to control. For example, controlling project-level managers that are reluctant to risk using BIM (vertex 20) is the key to improving the present situation. Managers at the project level are not very willing to adopt BIM technology because they are worried that adopting BIM to manage projects will lead to project failure. The use of BIM technology is often forced by corporate leaders for the future of the company or from government pressure. It is argued that aligning the interests of project-level managers and enterprise-level managers 
is critical to the application of BIM. Furthermore, how to reduce and eliminate BIM application barriers is a significant direction that deserves further research.

The identification and analysis of BIM application barriers is a significant elementary work for the whole systematic study of BIM development in the AEC industry. Government, project owners, consultants, designers, contractors, and software vendors are the key participants in applying BIM technology. They are the real executors and must work collaboratively to improve the effect of BIM application. Considering that they have participated in many BIM projects and mastered many BIM application materials, the creation of a BIM application barrier database (BABD) is recommended for eliminating barriers in BIM application, as shown in Figure 9. The research institution should be the primary undertaker of the establishment and maintenance of the BABD. Government, project owners, consultants, designers, and contractors must provide the engineering data and necessary help to research institutions. The successes and failures of BIM application can both be included in the BABD. Especially, the causes, interactions, and specific response measures of barriers should be important components of the BABD. According to the BABD, the stakeholders of the engineering project, such as government, owners, design units, and various contractors, could be clear about the challenges they are facing in overcoming BIM application barriers according to their roles in project construction, so as to put forward more accurate and targeted solutions for reducing the barriers and promoting the application of BIM in China's construction practice. The BABD can provide a reference for stakeholders to implement corresponding measures to control BIM application barriers and their influences more promptly and efficiently.

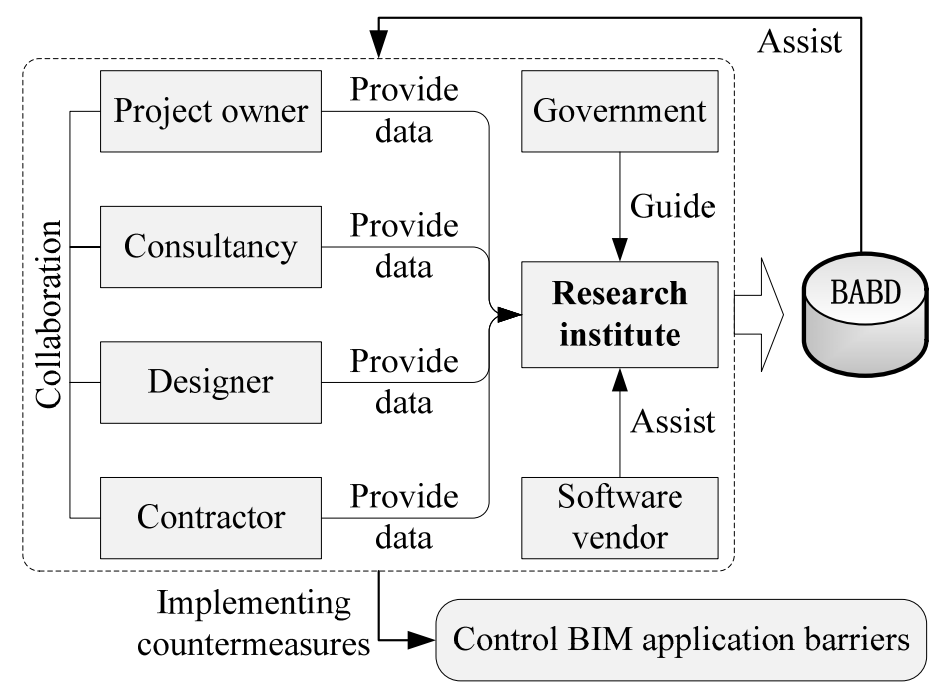

Figure 9. A proposed framework for controlling barriers.

\section{Conclusions}

Controlling and eliminating BIM application barriers will greatly promote the development of BIM. A new and effective analytical framework has been put forward to study BIM application barriers from the perspective of network, one that differs from the method of single factor analysis. The BABN was constructed by software Pajek based on 23 identified barriers and 178 interactions. As an unweighted directed network model, the BABN consists of 23 vertexes and 178 edges.

The main topological characteristics and network features of the BABN are identified and analyzed based on complex network theory. The average degree of the network is 15.57, which indicates that each barrier connects with 15 or 16 other barriers in the entire network. The "project-level managers are reluctant to risk using BIM" (vertex 20) has the highest degree and in-degree at the same time. The "insufficient government guidance (lack of relevant laws and standards)" (vertex 10) has the highest out-degree. The values of vertex betweenness centrality range from 0.0001 to 0.1170 . Furthermore, 
"the lack of BIM talents" (vertex 8), "project-level managers are reluctant to risk using BIM" (vertex 20) and "the holder of economic cost caused by BIM technology is not clear" (vertex 16) are the top three vertexes with the largest values of vertex betweenness. Prioritizing the control of these key barriers can effectively reduce a chain reaction. To soften or solve the barrier factors with a high degree and betweenness can largely raise the development level. The barriers with high eigenvector centrality but low betweenness comparatively are "leaders at the corporate level lack long-term vision and confidence" (vertex 5), "lack of BIM standards in line with market demand" (vertex 17), and "lack of a standard form of contract for BIM application" (vertex 18). Solving these key barriers will reduce not only their obstacles, but also those emerging from the important barriers associated with them. The vertex clustering coefficient in the BABN ranges from 0.5238 (vertex 19) to 0.3429 (vertex 20). Moreover, the clustering coefficient of the BABN is 0.4033 , which denotes that the BABN has a high degree of cliquishness. The network diameter of the BABN is 4 . The value of average path length in the BABN is 1.8044, suggesting that one barrier can transmit to another only in two steps on average. Furthermore, the BABN is a relatively small-world network according to its clustering coefficient and average path length, demonstrating that the barrier propagation in the BABN is fast. Therefore, it is of great significance to control the interactions between barrier factors. Due to the cumulative degree distribution of this network following a power-law distribution, it is also a scale-free network model. This indicates its robustness to random attacks and its vulnerability to deliberate attacks.

This paper consisted of three steps, including data collection, network modeling, and network analysis. Each step was essential to get the research results of this paper. The literature analysis laid the foundation for the acquisition of barriers and provided the necessary material for the interviews. Analyzing the interview content through grounded theory ensured the scientificity of the analysis and the integrity of the barriers. It was also necessary to obtain the relationships between barriers through the Delphi method. The Delphi method gave full play to the role of experts to ensure the accuracy of the relationships between barriers. Network theory processed the data and analyzed the barriers from a holistic perspective. Understanding the key barriers can greatly assist BIM stakeholders in developing BIM application strategies. In short, each step in this study is irreplaceable and indispensable. More importantly, according to the research process and results of this study, it would be feasible to apply this new analytical framework to similar studies in other countries and regions.

In a future study, how to control and eliminate the BIM application barriers is a question that is worth concerning and studying. Some promising information technologies are worth using to collect, analyze, visualize, and monitor valuable information to control BIM application barriers, such as knowledge bases and databases. The stakeholders will significantly benefit from this research. In addition, systematic and strong implementable solutions for promoting BIM development should be analyzed in depth.

Author Contributions: Conceptualization, J.L.; methodology, Y.D.; software, Q.W.; validation, N.X.; formal analysis, Y.D.; investigation, Q.W.; resources, S.P.; data curation, J.L.; writing一original draft preparation, S.P.; writing-review and editing, G.N.; visualization, Q.W.; supervision, N.X.; project administration, Y.D.; funding acquisition, Y.D. All authors have read and agreed to the published version of the manuscript.

Funding: The research described in this paper is supported by National Natural Science Foundation of China (71801214 and 71901206) and the Fundamental Research Funds for the Central Universities (2017QNB13). The authors also gratefully acknowledge those who provided data and suggestions.

Acknowledgments: The authors sincerely acknowledge the editors and anonymous reviewers for their valuable comments and constructive suggestions, which considerably improve the exposition of this work.

Conflicts of Interest: The authors declare no conflict of interest.

\section{References}

1. Heigermoser, D.; de Soto, B.G.; Abbott, E.L.S.; Chua, D.K.H. BIM-based Last Planner System tool for improving construction project management. Automat. Constr. 2019, 104, 246-254. [CrossRef] 
2. Azhar, S. Building Information Modeling (BIM): Trends, Benefits, Risks, and Challenges for the AEC Industry. Leadersh. Manag. Eng. 2011, 11, 241-252. [CrossRef]

3. Franz, B.; Messner, J. Evaluating the Impact of Building Information Modeling on Project Performance. J. Comput. Civ. Eng. 2019, 33, 04019015. [CrossRef]

4. Shin, M.H.; Lee, H.K.; Kim, H.Y. Benefit-Cost Analysis of Building Information Modeling (BIM) in a Railway Site. Sustainability 2018, 10, 4303. [CrossRef]

5. Chen, C.L.; Kou, W.W.; Ye, S.H. Research on the application of BIM technology in the whole life cycle of construction projects. In IOP Conference Series-Earth and Environmental Science; IOP Publishing: Bristol, UK, 2018; Volume 153.

6. Seyis, S. Pros and Cons of Using Building Information Modeling in the AEC Industry. Eng. Constr. Arch. Manag. 2019, 145, 04019046. [CrossRef]

7. Zhou, Y.; Yang, Y.; Yang, J. Barriers to BIM implementation strategies in China. Eng. Constr. Arch. Manag. 2019, 26, 554-574. [CrossRef]

8. Lin, J.R.; Zhang, J.P. Review and Exploratory Text Mining of Building Information Modeling Policies in China. Constr. Technol. 2018, 47, 73-78.

9. Bernstein, H.M.; Jones, S.A.; Gudgel, J.E. The Business value of BIM in China; Dodge Data and Analytics: Bedford, MA, USA, 2015.

10. Enterprises, E.B.O.B. BIM Application Analysis Report of Chinese Construction Enterprises, 1st ed.; China Architecture \& Building Press: Beijing, China, 2019; pp. 1-120.

11. Chen, K.; Lu, W.S.; Peng, Y.; Zheng, L.Z.; Niu, Y.H.; Rowlinson, S. An Investigation of the Latent Barriers to BIM Adoption and Development; Wu, Y., Zheng, S., Luo, J., Wang, W., Mo, Z., Shan, L., Eds.; Springer: Berlin/Heidelberg, Germany, 2017; pp. 1007-1017.

12. Zhou, W.; Qin, H.; Qiu, J.; Fan, H.; Lai, J.; Wang, K.; Wang, L. Building information modelling review with potential applications in tunnel engineering of China. R. Soc. Open Sci. 2017, 4, 170174. [CrossRef]

13. Yang, J.; Chou, H. Subjective benefit evaluation model for immature BIM-enabled stakeholders. Automat. Constr. 2019, 106, 106. [CrossRef]

14. Miettinen, R.; Paavola, S. Beyond the BIM utopia: Approaches to the development and implementation of building information modeling. Automat. Constr. 2014, 43, 84-91. [CrossRef]

15. Zheng, X.; Lu, Y.; Li, Y.; Le, Y.; Xiao, J. Quantifying and visualizing value exchanges in building information modeling (BIM) projects. Automat. Constr. 2019, 99, 91-108. [CrossRef]

16. Marzouk, M.; Al Daour, I. Planning labor evacuation for construction sites using BIM and agent-based simulation. Safety Sci. 2018, 109, 174-185. [CrossRef]

17. Zhang, L.; Chu, Z.; He, Q.; Zhai, P. Investigating the Constraints to Buidling Information Modeling (BIM) Applications for Sustainable Building Projects: A Case of China. Sustainability 2019, 11, 1896. [CrossRef]

18. Ustinovichius, L.; Peckiene, A.; Popov, V. A MODEL FOR SPATIAL PLANNING OF SITE AND BUILDING USING BIM METHODOLOGY. J. Civ. Eng. Manag. 2017, 23, 173-182. [CrossRef]

19. Hwang, B.; Zhao, X.; Yang, K.W. Effect of BIM on Rework in Construction Projects in Singapore: Status Quo, Magnitude, Impact, and Strategies. J. Constr. Eng. Manag. 2019, 145, 04018125. [CrossRef]

20. Lai, H.; Deng, X.; Chang, T.P. BIM-Based Platform for Collaborative Building Design and Project Management. J. Comput. Civ. Eng. 2019, 33, 05019001. [CrossRef]

21. Son, H.; Kim, C.; Cho, Y.K. Automated Schedule Updates Using As-Built Data and a 4D Building Information Model. J. Manag. Eng. 2017, 33, 04017012. [CrossRef]

22. Sigalov, K.; Konig, M. Recognition of process patterns for BIM-based construction schedules. Adv. Eng. Inform. 2017, 33, 456-472. [CrossRef]

23. Mansuri, D.; Chakraborty, D.; Elzarka, H.; Deshpande, A.; Gronseth, T. Building Information Modeling enabled Cascading Formwork Management Tool. Automat. Constr. 2017, 83, 259-272. [CrossRef]

24. Sheikhkhoshkar, M.; Rahimian, F.P.; Kaveh, M.H.; Hosseini, M.R.; Edwards, D.J. Automated planning of concrete joint layouts with 4D-BIM. Automat. Constr. 2019, 107, 102943. [CrossRef]

25. Kropp, C.; Koch, C.; Koenig, M. Interior construction state recognition with 4D BIM registered image sequences. Automat. Constr. 2018, 86, 11-32. [CrossRef] 
26. Chen, C.; Tang, L. BIM-based integrated management workflow design for schedule and cost planning of building fabric maintenance. Automat. Constr. 2019, 107, 102944. [CrossRef]

27. Peng, Y.; Lin, J.; Zhang, J.; Hu, Z. A hybrid data mining approach on BIM-based building operation and maintenance. Build. Environ. 2017, 126, 483-495. [CrossRef]

28. Won, J.; Cheng, J.C.P. Identifying potential opportunities of building information modeling for construction and demolition waste management and minimization. Automat. Constr. 2017, 79, 3-18. [CrossRef]

29. Xu, J.; Shi, Y.; Xie, Y.; Zhao, S. A BIM-Based construction and demolition waste information management system for greenhouse gas quantification and reduction. J. Clean Prod. 2019, 229, 308-324. [CrossRef]

30. Jiang, S.; Wang, N.; Wu, J. Combining BIM and Ontology to Facilitate Intelligent Green Building Evaluation. J. Comput. Civ. Eng. 2018, 32, 04018039. [CrossRef]

31. Ansah, M.K.; Chen, X.; Yang, H.; Lu, L.; Lam, P.T.I. A review and outlook for integrated BIM application in green building assessment. Sustain. Cities Soc. 2019, 48, 101576. [CrossRef]

32. Li, X.; Xu, J.; Zhang, Q. Research on construction schedule management based on BIM technology. Procedia Eng. 2017, 174, 657-667. [CrossRef]

33. Wei, H.; Zheng, S.; Zhao, L.; Huang, R. BIM-based method calculation of auxiliary materials required in housing construction. Automat. Constr. 2017, 78, 62-82. [CrossRef]

34. Mirshokraei, M.; De Gaetani, C.I.; Migliaccio, F. A Web-Based BIM-AR Quality Management System for Structural Elements. Appl. Sci. 2019, 9, 3984. [CrossRef]

35. Ahmad, Z.; Thaheem, M.J.; Maqsoom, A. Building information modeling as a risk transformer: An evolutionary insight into the project uncertainty. Automat. Constr. 2018, 92, 103-119. [CrossRef]

36. Fountain, J.; Langar, S. Building Information Modeling (BIM) outsourcing among general contractors. Automat. Constr. 2018, 95, 107-117. [CrossRef]

37. Piroozfar, P.; Farr, E.R.P.; Zadeh, A.H.M.; Inacio, S.T.; Kilgallon, S.; Jin, R. Facilitating Building Information Modelling (BIM) using Integrated Project Delivery (IPD): A UK perspective. J. Build. Eng. 2019, 26, 26. [CrossRef]

38. Charef, R.; Emmitt, S.; Alaka, H.; Fouchal, F. Building Information Modelling adoption in the European Union: An overview. J. Build. Eng. 2019, 25, 100777. [CrossRef]

39. Khodeir, L.M.; Nessim, A.A. BIM2BEM integrated approach: Examining status of the adoption of building information modelling and building energy models in Egyptian architectural firms. Ain Shams Eng. J. 2018, 9, 1781-1790. [CrossRef]

40. Doan, D.T.; Ghaffarianhoseini, A.; Naismith, N.; Ghaffarianhoseini, A.; Zhang, T.; Tookey, J. Examining Green Star certification uptake and its relationship with Building Information Modelling (BIM) adoption in New Zealand. J. Environ. Manag. 2019, 250, 109508. [CrossRef]

41. Bosch-Sijtsema, P.M.; Gluch, P.; Sezer, A.A. Professional development of the BIM actor role. Automat. Constr. 2019, 97, 44-51. [CrossRef]

42. Liu, H.; Liu, Y.; Xin, T. The Obstruction to the use of Building Information Modeling in China. In Applied Mechanics and Materials; Galkowski, K., Kim, Y.H., Eds.; Trans Tech Publications Ltd.: Zürich, Switzerland, 2013; pp. 2313-2316.

43. Ji, B.Y.; Qi, Z.Q.; Jin, Z.Y. Based on Game Model to Design of Building Information Modeling Application Policy. In Proceedings of the 2014 Fifth International Conference on Intelligent Systems Design and Engineering Applications; Institute of Electrical and Electronics Engineers, Zhangjiajie, China, 15-16 June 2014; pp. 1069-1073.

44. Liu, H.; Zhao, J. The Analysis of Resistances that Hamper the Use of BIM in China. Appl. Mech. Mater. 2014, 519, 1447-1450. [CrossRef]

45. Sun, J.; Wang, L. The Interaction between Bim's Promotion and Interest Game under Information Asymmetry. J. Ind. Manag. Optim. 2015, 11, 1301-1319. [CrossRef]

46. Li, H.; Ng, S.T.T.; Skitmore, M.; Zhang, X.; Jin, Z. Barriers to building information modelling in the Chinese construction industry. Munic. Eng. 2017, 170, 105-115. [CrossRef]

47. Dong, N.; Guo, J.N.; Jiang, T. Study on Barriers to BIM-based Cost Analysis and Development Path Using DEMATEL Method. J. Eng. Manag. 2020, 34, 1-5. 
48. Olawumi, T.O.; Chan, D.W.M.; Wong, J.K.W.; Chan, A.P.C. Barriers to the integration of BIM and sustainability practices in construction projects: A Delphi survey of international experts. J. Build. Eng. 2018, 20, 60-71. [CrossRef]

49. Mehran, D. Exploring the Adoption of BIM in the UAE construction industry for AEC firms. Procedia Eng. 2016, 145, 1110-1118. [CrossRef]

50. Kim, S.; Park, C.H.; Chin, S. Assessment of BIM acceptance degree of Korean AEC participants. Ksce J. Civ. Eng. 2016, 20, 1163-1177. [CrossRef]

51. Abbasianjahromi, H.; Ahangar, M.; Ghahremani, F. A Maturity Assessment Framework for Applying BIM in Consultant Companies. Ijst-T Civ. Eng. 2019, 431, 637-649. [CrossRef]

52. Liao, L.; Teo, E.A.L. Critical success factors for enhancing the building information modelling implementation in building projects in singapore. J. Civ. Eng. Manag. 2017, 23, 1029-1044. [CrossRef]

53. Ma, G.; Jia, J.; Ding, J.; Shang, S.; Jiang, S. Interpretive Structural Model Based Factor Analysis of BIM Adoption in Chinese Construction Organizations. Sustainability 2019, 11, 1982. [CrossRef]

54. Liu, H.L.; Song, J.L.; Wang, G.B.; Cao, D.P.; Li, Y. User satisfaction of building information modeling (BIM) and its influencing factors in AEC industry. China Civ. Eng. J. 2019, 52, 118-128.

55. Glaser, B.G.; Strauss, A.L. The Discovery of Grounded Theory: Strategies for Qualitative Research. In Aldine; De Gruyter: New York, NY, USA, 1967; pp. 1-271.

56. Kennedy, T.; Lingard, L.A. Making sense of grounded theory in medical education. Med. Educ. 2006, 40, 101-108. [CrossRef]

57. Stol, K.J.; Ralph, P.; Fitzgerald, B. Grounded Theory in Software Engineering Research: A Critical Review and Guidelines. In Proceedings of the International Conference on Software Engineering, Austin, TX, USA, 14-22 May 2016; pp. 120-131.

58. Li, X.; Du, J.; Long, H. Green Development Behavior and Performance of Industrial Enterprises Based on Grounded Theory Study: Evidence from China. Sustainability 2019, 11, 4133. [CrossRef]

59. Liu, Y.; Van Nederveen, S.; Hertogh, M. Understanding effects of BIM on collaborative design and construction: An empirical study in China. Int. J. Proj. Manag. 2017, 35, 686-698. [CrossRef]

60. Glaser, B. Theoretical Sensitivity: Advances in the methodogy of Grounded Theory; Sociology Press: Mill Valley, CA, USA, 1978.

61. Okoli, C.; Pawlowski, S.D. The Delphi method as a research tool: An example, design considerations and applications. Inform. Manag. Amster. 2004, 42, 15-29. [CrossRef]

62. Schumaier, A.; Kovacevic, D.; Schmidt, C.; Green, A.; Rokito, A.; Jobin, C.; Yian, E.; Cuomo, F.; Koh, J.; Gilotra, M.; et al. Defining massive rotator cuff tears: A Delphi consensus study. J. Shoulder Elb. Surg. 2020, 29, 674-680. [CrossRef] [PubMed]

63. Dupras, C.; Birko, S.; Affdal, A.O.; Haidar, H.; Lemoine, M.; Ravitsky, V. Governing the futures of non-invasive prenatal testing: An exploration of social acceptability using the Delphi method. Soc. Sci. Med. 2020, 112930. [CrossRef]

64. Clark, C.R.; Heimlich, J.E.; Ardoin, N.M.; Braus, J. Using a Delphi study to clarify the landscape and core outcomes in environmental education. Environ. Educ. Res. 2020. [CrossRef]

65. Grisham, T. The Delphi technique: A method for testing complex and multifaceted topics. Int. J. Manag. Proj. Bus. 2009, 2, 112-130. [CrossRef]

66. Strand, J.; Carson, R.T.; Navrud, S.; Ortiz-Bobea, A.; Vincent, J.R. Using the Delphi method to value protection of the Amazon rainforest. Ecol. Econ. 2017, 131, 475-484. [CrossRef]

67. Hearnshaw, E.J.S.; Wilson, M.M.J. A complex network approach to supply chain network theory. Int. J. Oper. Prod. Manag. 2013, 33, 442-469. [CrossRef]

68. Mendes, G.A.; Da Silva, L.R.; Herrmann, H.J. Traffic gridlock on complex networks. Physica 2012, 391, 362-370. [CrossRef]

69. Gan, C.; Yang, X.; Liu, W.; Zhu, Q.; Jin, J.; He, L. Propagation of computer virus both across the Internet and external computers: A complex-network approach. Commun. Nonlinear Sci. 2014, 19, 2785-2792. [CrossRef]

70. Watts, D.J.; Strogatz, S.H. Collective dynamics of 'small-world' networks. Nature 1998, 393, 440-442. [CrossRef] [PubMed] 
71. Barabasi, A.L.; Albert, R. Emergence of scaling in random networks. Science (New York, N.Y.) 1999, 286, 509-512. [CrossRef] [PubMed]

72. Liu, T.; Chen, Z.; Chen, X.R. A Brief Review of Complex Networks and Its Application. Syst. Eng. 2005, 23, 1-7.

73. Mrvar, A.; Batagelj, V. Analysis and visualization of large networks with program package Pajek. Complex Adapt. Syst. Model. 2016, 4, 47. [CrossRef]

74. Tan, T.; Chen, K.; Xue, F.; Lu, W. Barriers to Building Information Modeling (BIM) implementation in China's prefabricated construction: An interpretive structural modeling (ISM) approach. J. Clean Prod. 2019, 219, 949-959. [CrossRef]

75. Liu, H.; Liu, Q. Research on the Development Barriers of BIM in China. Appl. Mech. Mater. 2014, 525, 691-694. [CrossRef]

76. Zhang, S.X.; Hu, Y.R. The analysis of barriers of development of China's construction industry BIM. Adv. Mater. Res. 2014, 838-841, 3119-3122. [CrossRef]

77. Chan, D.W.M.; Olawumi, T.O.; Ho, A.M.L. Perceived benefits of and barriers to Building Information Modelling (BIM) implementation in construction: The case of Hong Kong. J. Build. Eng. 2019, 25, 100764. [CrossRef]

78. Zhang, C.X. Research on the application status and development obstacles of BIM Technology in China's construction industry. Constr. Econ. 2011, 09, 96-98.

79. Zhao, X.Y.; Dong, N. The Application Obstacles in BIM and Its Solving Measures in the Design Phase. Constr. Technol. 2015, 44, 667-670.

80. Shen, L.; Song, J.R.; Qian, J. Key Factors and Countermeasures of BIM Application Benefit Based on DEMATEL Model. J. Civ. Eng. Manag. 2018, 35, 45-51.

81. Xie, T.R.; She, J.J.; Song, J.R. Countermeasure Research on Promoting BIM Based on the Analysis of Key Cost Factors. J. Civ. Eng. Manag. 2018, 35, 152-157.

82. Feng, J.C.; Zhao, Y.P. Research on the Barriers of BIM Application in the Construction Project Management. Sci. Technol. Manag. Res. 2017, 37, 202-209.

83. Qiu, G.F.; Li, Z.H. Study on the Obstacle Factors of BIM Application from the Architectural Supply Chain Perspective. J. Civ. Eng. Manag. 2019, 36, 21-27.

84. Zhang, J.X. Study on Barriers of Implementing BIM in Engineering Design Industry in China. J. Eng. Manag. 2010, 24, 387-392.

85. Gao, M.; Hao, S.Y. A Study of Influencing Factors for BIM Application in Chinese Construction Industry Based on Factor Analysis. J. Eng. Manag. 2019, 33, 38-42.

86. Wan, L.; Huang, J.G. Research on the Application Status and Obstacles of BIM Technology in Construction Industry of Zhanjiang City. Constr. Econ. 2019, 40, 116-120.

87. Pan, J.Y.; Zhao, Y.Y. Research on Barriers of BIM Application in China's Building Industry. J. Eng. Manag. 2012, 26, 6-11.

88. He, Q.H.; Qian, L.L.; Duan, Y.F.; Li, Y.K. Current Situation and Barriers of BIM Implementation. J. Eng. Manag. 2012, 26, 12-16.

89. Qin, X.; Mauro, M.; Agnese, T.; Lv, K.C.; Wang, M. A Comparative Study on Barriers between China and Italy in BIM Adoption from the Construction Market Perspective. Chin. J. Manag. 2016, 13, 1718-1727.

90. He, Q.H.; Zhang, J. Study on Barriers of Building Information Modeling Application in Building Construction Enterprises. Constr. Technol. 2012, 41, 80-83.

91. Zhou, Y.; Li, X.; Chen, Y.X. Obstacles and Countermeasures of Building Information Model Application in Engineering Design. Constr. Econ. 2012, 11, 101-104.

92. Chan, C. BIM from Design Stage-Are Hong Kong Designers Ready? Zhang, R., Zhang, Z., Liu, K., Zhang, J., Eds.; Springer: Berlin/Heidelberg, Germany, 2015; pp. 271-276.

93. Fan, S. Intellectual Property Rights in Building Information Modeling Application in Taiwan. J. Constr. Eng. Manag. 2014, 140, 04013058. [CrossRef]

94. Ji, B.Y.; Qi, Z.Q.; Jin, Z.Y. Obstacles and Countermeasures for BIM Application in Building Industry Based on the Externalities Analysis. Constr. Technol. 2014, 43, 84-87.

95. Hallowell, M.R.; Gambatese, J.A. Qualitative Research: Application of the Delphi Method to CEM Research. J. Constr. Eng. Manag. 2010, 136, 99-107. [CrossRef] 
96. Yang, R.J.; Zou, P.X.W.; Wang, J. Modelling stakeholder-associated risk networks in green building projects. Int. J. Proj. Manag. 2016, 34, 66-81. [CrossRef]

97. Newman, M. Scientific collaboration networks. II. Shortest paths, weighted networks, and centrality. Phys. Rev. E 2001, 64, 016132. [CrossRef]

98. Du, Q.; Guo, X.; Bao, T.; Huang, Y.; Han, X. CO2 flows in the inter-regional and inter-sectoral network of the Yangtze River Economic Zone. Environ. Sci. Pollut. Res. 2020. [CrossRef] 